\title{
Pengaruh Kinerja Pelayanan Transportasi Pada Komoditi Unggulan Terhadap Pengembangan Wilayah di Kabupaten Sinjai
}

\section{The Effect of Performance of Transportation Services in Superior Commodities on Regional Development in Sinjai District}

\author{
Amran Libureng \\ Magister Perencanaan Wilayah dan Kota Program Pascasarjana Universitas Bosowa \\ E-mail: amranbone@gmail.com
}

Diterima: 06 Maret 2019/Disetujui 10 Juni 2019

\begin{abstract}
Abstrak. Kabupaten Sinjai merupakan salah satu kabupaten di Sulawesi Selatan yang memiliki potensi ekonomi yang tinggi, khususnya di sektor pertanian dalam hal ini komoditi unggulan. Hal ini bisa dilihat dari sisi output (PDRB) maupun dari sisi penyerapan dari potensi tenaga kerja, dengan angka masing-masing sebesar 29,47 persen dan 52,72 persen terhadap total PDRB dan (BPS Kabupten Sinjai, 2012)). Dalam rangka pengembangan komoditi unggulan di Kecamatan Sinjai Barat tersebut, pemerintah daerah telah membangun prasarana transportasi pada 34 titik pada TA : 2007-2009 yang bersumber dari dana APBD dan PNPM. Pemerintah berpendapat bahwa bidang transportasi ini perlu mendapat perhatian dan bantuan, bahkan bagian-bagian yang terpenting di bidang transportasi perlu diusahakan. Rumusan masalah ; Bagaimana Model Regeresi dan Persepsi masyarakat pada pengaruh prasarana jalan, sistem transportasi, Kebijakan, SDM dan Perilaku Pengguna Jasa terhadap Kinerja Pelayanan Transportasi diwilayah penelitian, Tujuan penelitian adalah menganalisis Model Regeresi, dan Persepsi masyarakat pada prasarana jalan, sistem transportasi, Kebijakan, SDM dan Perilaku Pengguna Jasa terhadap Kinerja Pelayanan Transportasi diwilayah penelitian. Jenis penelitian merupakan deskriptif analisis kualitatif melalui responden yang diambil diwilayah penelitian didua Kecamatan, Metode penelitiam yaitu Regeresi Linear Berganda.. Hasil pembahasan yaitu, Model regeresi yang diperoleh berdasar padahasil analisis dan pembahasan, yaitu $: Y=0,092+(-$ 0,119).X1 + 0,587.X2 + 0,203.X4 + 0,325.X5 $(\mathrm{R} 2=0,701)$. Berdasarkan persamaan model: Untuk responden menyatakan penting pada prasasarana transportasi (X1) sebesar, 75\%. Sistem transportasi (X2) sebesar 55\%. Kebijakan (X3) sebesar 55\%. SDM (X4) sebesar 65\%. Perilaku Pengguna Jasa (X5) sebesar 55\%.
\end{abstract}

Kata Kunci: Pengembangan, Ekonomi, Infrastruktur, Aksesibilitas, Partisipasi

\begin{abstract}
Sinjai Regency is one of the districts in South Sulawesi that has high economic potential, especially in the agricultural sector in this case the leading commodity. This can be seen in terms of output (GRDP) and in terms of absorption from the potential of labor, with figures of 29.47 percent and 52.72 percent of total GRDP and (BPS Kabupten Sinjai, 2012)). In the framework of developing superior commodities in the West Sinjai District, the regional government has built transportation infrastructure at 34 points on TA: 2007-2009 sourced from APBD and PNPM funds. The government is of the opinion that this transportation sector needs attention and assistance, even the most important parts in the transportation sector need to be sought. Formulation of the problem; What is the Regeresi Model and Community Perception on the influence of road infrastructure, transportation system, Policy, HR and Service User Behavior on Transportation Service Performance in the research area, The research objective is to analyze Regression Model, and public perception on road infrastructure, transportation system, Policy, HR and Behavior Service Users on Transportation Service Performance in the research area. This type of research is descriptive qualitative analysis through respondents taken in the research area in two subdistricts, the research method namely Multiple Linear Regeresi .. The results of the discussion are, Regeresi model obtained based on the results of analysis and discussion, namely: $Y=0.092+(-0.119) . X 1+0.587 . X 2+$ 0.203.X4 + 0.325.X5 (R2 = 0.701). Based on the model equation: For respondents, the importance of transportation infrastructure (X1) is equal to, 75\%. The transportation system (X2) is 55\%. Policy (X3) of 55\%. SDM (X4) of 65\%. Service User Behavior (X5) of 55\%.
\end{abstract}

Keywords: Development, Economy, Infrastructure, Accessibility, Participation

\section{Pendahuluan}

Kabupaten Sinjai merupakan salah satu kabupaten di Sulawesi Selatan yang memiliki potensi ekonomi yang tinggi, khususnya di sektor pertanian dalam hal ini komoditi unggulan. Hal ini bisa dilihat dari potensi sektor pertanian yang merupakan sektor basis, baik dilihat dari sisi output (PDRB) maupun dari sisi penyerapan tenaga kerja, dimana peranan masing-masing sebesar 29,47 persen dan 
52,72 persen terhadap total PDRB dan total penyerapan tenaga kerja (BPS Kabupten Sinjai, 2012).

Salah satu upaya untuk mewujudkan pembangunan sektor pertanian di Kabupaten Sinjai yaitu dengan menetapkan komoditas unggulan serta kawasan sentra produksinya, sebagaimana halnya komoditi unggulan holtikultura (sayuran) dan sapi yang kawasan sentra produksinya berada di Kecamatan Sinjai Barat. Dalam rangka pengembangan komoditi unggulan di Kecamatan Sinjai Barat tersebut, pemerintah daerah Kabupaten Sinjai telah membangun prasarana transportasi yang terdapat pada 34 titik dari tahun anggaran $2007-2009$ yang bersumber dari dana APBD dan PNPM

Namun, pembangunan prasarana tranportasi tersebut ternyata belum mampu memaksimalkan peran komoditas unggulan terhadap pertumbuhan ekonomi di Kecamatan Sinjai Barat. Data kontribusi komoditi unggulan sayuran dan sapi terhadap PAD untuk periode 2007-2010 di wilayah Kecamatan Sinjai Barat tidak menunjukkan peningkatan yang berarti, yakni masih jauh dibawah target yang diharapkan (Dinas Pertanian Kabupaten Sinjai, 2011). Padahal dengan adanya transportasi, diharapkan dapat menghilangkan isolasi dan memberi stimulan ke arah perkembangan agribisnis komoditi unggulan, baik budidaya, perdagangan maupun industri pengolahan.

Secara umum transportasi dapat didefinisikan sebagai suatu kegiatan untuk mengangkut atau memindahkan sesuatu barang atau penumpang dari suatu tempat ke tempat lain yang terpisah secara spasial, baik dengan atau tanpa sarana/alat angkut. Infrastruktur transportasi mencakup transportasi jalan, perkeretaapian, angkutan sungai, danau dan penyeberangan, transportasi laut dan transportasi udara.

Pengertian transportasi yang dikemukakan oleh Nasution (1996), diartikan sebagai pemindahan barang dan manusia dari tempat asal ke tempat tujuan. Sehingga dengan kegiatan tersebut maka terdapat tiga hal yaitu adanya muatan yang diangkut, tersedianya kendaraan sebagai alat angkut, dan terdapatnya jalan yang dapat dilalui. Proses pemindahan dari gerakan tempat asal, dimana kegiatan pengangkutan dimulai dan ke tempat tujuan dimana kegiatan diakhiri. Untuk itu dengan adanya pemindahan barang dan manusia tersebut, maka transportasi merupakan salah satu sektor yang dapat menunjang kegiatan ekonomi (the promoting sector) dan pemberi jasa (the servicing sector) bagi perkembangan ekonomi.

Pengertian lainnya dikemukakan oleh Soesilo (1999), yang mengemukakan bahwa transportasi merupakan pergerakan tingkah laku orang dalam ruang baik dalam membawa dirinya sendiri maupun membawa barangbarang. Menurut Salim (2012), faktor eksternal yang mempengaruhi transportasi antara lain: (1) Undangundang/Peraturan Pemerintah, (2) Kebijaksanaan/ Pengaturan pihak pemerintah dan (3) Pengaruh pemakai jasa. Menurut Siregar (1990), dari segi nasional ada beberapa faktor yang harus diciptakan agar sistem transportasi berhasil dan mencapai tujuan yaitu (1) Sarana dan Prasarana transportasi serta komunikasi yang baik, (2) Peraturan perundang-undangan yang mendukung, (3) Keserasian hubungan antar moda baik secara teknis maupun sistem operasi dan (4) Tersedianya informasi yang akurat tentang kegiatan transportasi.

Menurut Pahlevi (2006), ada lima unsur pokok transportasi, yaitu: (1) Manusia, yang membutuhkan transportasi; (2) Barang, yang dibutuhkan manusia; (3) Kendaraan, sebagai sarana transportasi; (4) Jalan, sebagai prasarana transportasi; dan (5) Organisasi, sebagai pengelola angkutan. Pada dasarnya, ke lima unsur tersebut saling terkait untuk terlaksananya transportasi yang menjamin penumpang atau barang yang diangkutnya akan sampai ke tempat tujuan dalam keadaan baik seperti pada saat awal diangkut.

Selain itu, Tamin (1997), mengungkapkan bahwa, prasarana transportasi mempunyai dua peran utama, yaitu: (1) sebagai alat bantu untuk mengarahkan pembangunan di daerah perkotaan; dan sebagai prasarana bagi pergerakan manusia dan atau barang yang timbul akibat adanya kegiatan di daerah perkotaan tersebut. Dengan melihat dua peran yang di sampaikan di atas, peran pertama sering digunakan oleh perencana pengembangan wilayah untuk dapat mengembangkan wilayahnya sesuai dengan rencana.

Misalnya saja akan dikembangkan suatu wilayah baru dimana pada wilayah tersebut tidak akan pernah ada peminatnya bila wilayah tersebut tidak disediakan sistem prasarana transportasi. Sehingga pada kondisi tersebut, parsarana transportasi akan menjadi penting untuk aksesibilitas menuju wilayah tersebut dan akan berdampak pada tingginya minat masyarakat untuk menjalankan kegiatan ekonomi. Hal inimerupakan penjelasan peran prasarana transportasi yang kedua, yaitu untuk mendukung pergerakan manusia dan barang.

Manusia untuk memenuhi kebutuhannya harus menggunakan sumber daya alam yang menyediakan makanan dan minuman, pakaian dan perumahan sebagai tempat tinggal dengan harapan untuk mendapatkan penghidupan yang layak dan nyaman serta tentram, akan tetapi keberadaan sumber daya alam dipermukaan bumi tidak merata karena keadaan alam itu sendiri. Tidak ada satu wilayah di dunia ini yang dalam memenuhi kebutuhan akan sumber daya alam di wilayahnya berasal hanya dari wilayah itu sendiri, dengan demikian manusia harus melakukan transportasi dengan melintasi berbagai kondisi alam. Transportasi yang baik akan berperan penting dalam perkembangan wilayah terutama dalam aksesibilitas, adapun yang dimaksud dengan aksesibilitas adalah kemudahan dan kemampuan suatu wilayah atau ruang untuk diakses atau dijangkau oleh pihak dari luar daerah tersebut baik secara langsung maupun tidak langsung. Mudahnya suatu lokasi dihubungkan dengan lokasi lainnya lewat jaringan transportasi yang ada, berupa prasarana jalan dan alat angkut yang bergerak diatasnya. Pembangunan pedesaan semakin lambat dan terhambat karena kurangnya sarana transportasi yang ada (Margaretta, 2000).

Menurut Salim (2000) transportasi bermanfaat bagi masyarakat, dalam arti hasil-hasil produksi dan bahanbahan baku suatu daerah dapat dipasarkan kepada perusahaan industri. Selain itu transportasi melaksanakan penyebaran penduduk dan pemerataan pembangunan. Penyebaran penduduk ke seluruh pelosok tanah air di Indonesia menggunakan berbagai jenis moda transportasi.

Menurut Daljoeni (2003) tentang peran transportasi dalam menghubungkan bahan baku ke konsumen, 
pengangkutan berperan penting untuk saling menghubungkan daerah sumber bahan baku, daerah produksi, daerah pemasaran dan daerah pemukiman sebagai tempat tinggal konsumen. Untuk mendukung transportasi dibutuhkan alat angkut berupa kendaraan, sehingga perusahaan otomotif dapat memproduksi berbagai jenis kendaraan. Pendapat Warpani (1990) bahwa pengangkutan diperlukan karena sumber-sumber kebutuhan manusia disuatu daerah tidak terdapat di setiap tempat. Disamping itu sumber daya yang dibutuhkan harus melalui tahapan produksi, dimana lokasinya tidak selalu terdapat ditempat manusia sebagai konsumen.

Menurut Soesilo (1998), transportasi memiliki manfaat yang sangat besar dalam mengatasi permasalahan suatu daerah, yaitu sebagai berikut: $1 . \quad$ Penghematan biaya operasi, penghematan ini akan sangat dirasakan bagi perusahaan yang menggunakan alat pengangkutan, seperti bus dan truk. Penghematan timbul karena bertambah baiknya keadaan sarana angkutan dan besarnya berbedabeda sesuai dengan jenis kendaraanya dan kondisi sarananya, 2. Penghematan waktu, manfaat lainnya yang menjadi penting dengan adanya proyek transportasi adalah penghematan waktu bagi penumpang dan barang. Bagi penumpang, penghematan waktu dapat dikaitkan dengan banyaknya pekerjaan lain yang dapat dilakukan oleh penumpang tersebut. Untuk menghitungnya, dapat dihitung dengan jumlah penumpang yang berpergian untuk satu usaha jasa saja dan dapat pula dihitung dengan tambahan waktu senggang atau produksi yang timbul apabila semua penumpang dapat mencapai tempat tujuan dengan lebih cepat. Adapun manfaat dari penghematan waktu tersebut dapat dihitung dengan mengalikan perbedaan waktu tempuh dengan rata-rata pendapatan per jam dari jumlah pekerja yang menggunakan fasilitas tersebut. Manfaat penghematan waktu untuk barang terutama dilihat pada barang-barang yang cepat turun nilainya jika tidak segera sampai di pasar, seperti sayur-sayuran, buah-buahan dan ikan. Manfaat lain akibat adanya penghematan waktu tempuh adalah biaya modal (modal atas modal kerja) sehubungan dengan pengadaan persediaan. 3.Pengurangan kecelakaan, untuk proyekproyek tertentu, pengurangan kecelakaan merupakan suatu manfaat yang nyata dari keberadaan transportasi. Seperti perbaikan sarana transportasi pelayaran, jalan kereta api dan sebagainya telah dapat mengurangi kecelakaan. Namun di Indonesia, masalah ini masih banyak belum mendapat perhatian, sehingga sulit memperkirakan besarnya manfaat karena pengurangan biaya kecelakaan. Jika kecelakaan meningkat dengan adanya peningkatan sarana dan prasarana transportasi, hal ini menjadi tambahan biaya atau bernilai manfaat negatif, 4.Manfaat akibat perkembangan ekonomi, pada umumnya kegiatan transportasi akan memberikan dampak terhadap kegiatan ekonomi suatu daerah. Besarnya manfaat ini sangat bergantung pada elastisitas produksi terhadap biaya angkutan. Tambahan output dari kegiatan produksi tersebut dengan adanya jalan dikurangi dengan nilai sarana produksi merupakan benefit dari proyek tersebut, 5. Manfaat tidak langsung, merupakan manfaat yang didapat karena terhubungnya suatu daerah dengan daerah lain melalui jalur transportasi. Selain manfaat karena terintegrasinya dua daerah tersebut, maka akan terjadi pemerataan pendapatan dan prestise, sehingga manfaat ini sangat sulit untuk diperhitungkan secara kuantitatif.

Kemajuan transportasi akan membawa peningkatan mobilitas manusia, mobilitas faktor-faktor produksi dan mobilitas hasil olahan yang dipasarkan. Makin tinggi mobilitas yang dilakukan maka semakin cepat gerakan distribusi serta lebih singkat waktu yang diperlukan dalam mengolah bahan dan memindahkannya dari tempat dimana bahan tersebut yang semula kurang bermanfaat kelokasi dimana manfaatnya lebih besar. Peningkatan produktivitas, karena transportasi ini merupakan motor utama penggerak kemajuan ekonomi. Ekonomi yang berkembang akan ditunjukkan oleh adanya mobilitas yang tinggi, dengan ditunjang transportasi yang memadai dan lancar. Seperti halnya negara-negara maju, mereka memiliki transportasi yang mendukung dalam setiap aktivitas yang mereka lakukan. Dengan transportasi yang baik, akan memudahkan terjadinya interaksi antara penduduk lokal dengan dunia luar. Keterisolasian merupakan masalah pertama yang harus ditangani dengan prasarana transportasi (Tamin, 1997).

Menurut Hurst (1974), bahwa interaksi antar wilayah tercermin pada keadaan fasilitas transportasi serta aliran orang, barang, maupun jasa. Transportasi merupakan tolok ukur dalam interaksi keruangan antar wilayah dan sangat penting peranannya dalam menunjang proses perkembangan suatu wilayah. Perkembangan ini telah memupus kegelapan dalam kehidupan manusia yang tidak terjamah oleh kemajuan dalam jangka waktu yang lama. Transportasi dapat memajukan kesejahteraan ekonomi dan masyarakat, menciptakan dan meningkatkan tingkat aksesibilitas dari potensi-potensi sumber alam dan luas pasar. Sumber alam yang semula tidak termanfaatkan akan terjangkau dan dapat diolah. Faktor perkembangan wilayah yakni modal, tenaga kerja, perlengkapan SDA dan pasar merupakan kesatuan yang saling berkaitan dan nantinya menghasilkan interaksi dan menciptakan kegiatan ekonomi, sosial maupun politik.

Menurut Bintarto (1982), perpindahan manusia dan barang dari satu tempat ke tempat lain selalu melalui jalurjalur tertentu. Tempat asal dan tempat tujuan dihubungkan satu sama lain dengan suatu jaringan (network) dalam ruang. Jaringan tersebut dapat berupa jaringan jalan, yang merupakan bagian dari sistem transportasi. Transportasi merupakan hal yang penting dalam suatu sistem, karena tanpa transportasi perhubungan antara satu tempat dengan tempat lain tidak terwujud secara baik. Menurut Hurst (1974), mengemukakan bahwa interaksi antar wilayah tercermin pada keadaan fasilitas transportasi serta aliran orang, barang, maupun jasa. Transportasi merupakan tolok ukur dalam interaksi keruangan antar wilayah dan sangat penting peranannya dalam menunjang proses perkembangan suatu wilayah. Wilayah dengan kondisi geografis yang beragam memerlukan keterpaduan antar jenis transportasi dalam melayani kebutuhan masyarakat. Pada dasarnya, sistem transportasi dikembangkan untuk menghubungkan dua lokasi guna lahan yang mungkin berbeda. Transportasi digunakan untuk memindahkan 
orang atau barang dari satu tempat ke tempat lain sehingga mempunyai nilai ekonomi yang lebih meningkat.

Transportasi erat sekali dengan penggudangan atau penyimpanan karena keduanya meningkatkan manfaat barang. Angkutan menyebabkan barang dapat dipindahkan dari satu tempat ke tempat lain sehingga bisa dipergunakan di tempat barang itu tidak didapatkan. Dengan demikian menciptakan manfaat tempat. Penyimpanan atau penggudangan juga memungkinakan barang disimpan sampai dengan waktu dibutuhkan dan ini berarti memberi manfaat waktu (Schumer, 1974).

Pemerintah pada umumnya memandang bahwa bidang transportasi adalah sangat vital untuk kepentingan negara baik dari sudut perekonomian maupun dari sudut sosial, politik, pemerintahan, pertahanan, dan keamanan, dan sebagainya, yang mana sebagian besar pendanaannya masih tergantung pada pemerintah. Pemerintah berpendapat bahwa bidang transportasi ini perlu mendapat perhatian dan bantuan, bahkan bagianPemerintah pada umumnya memandang bahwa bidang transportasi adalah sangat vital untuk kepentingan negara baik dari sudut perekonomian maupun dari sudut sosial, politik, pemerintahan, pertahanan, dan keamanan, dan sebagainya, yang mana sebagian besar pendanaannya masih tergantung pada pemerintah. Pemerintah berpendapat bahwa bidang transportasi ini perlu mendapat perhatian dan bantuan, bahkan bagian -bagian yang terpenting di bidang transportasi perlu diusahakan oleh pemerintah.

Rumusan masalah pada penelitian ini adalah bagaimana pengaruh, model regresi dan persepsi responden pada faktor sarana dan prasarana, sistem transportasi, Kebijakan Pemerintah, Sumber Daya Manusia dan Perilaku Pengguna Jasa dan Kinerja Pelayanan Transportasi terhadap pengembangan wilayah kabupaten.

Berdasarkan rumusan masalah maka tujuan penelitian ini adalah untuk menganalisis pengaruh, model regresi dan perepsi responden pada faktor sarana dan prasarana, sistem transportasi, Kebijakan Pemerintah, Sumber Daya Manusia dan Perilaku Pengguna Jasa dan Kinerja Pelayanan Transportasi terhadap pengembangan wilayah kabupaten.

\section{Metode Penelitian}

\section{a. Jenis dan Desain Penelitian}

Jenis penelitian yang digunakan adalah penelitian deskriptif yaitu memberikan gambaran yang lebih detail mengenai sutau gejala atau fenomena yang terjadi dilapangan serta menjelaskan pengaruh dari berbagai variabel melalui pengujian hipotesis. Desain penelitian menggunakan metode survei yaitu pengamatan langsung dilapangan.

Peneltian ini dilaksanakan di Kecamatan Sinjai Barat Kabupaten Sinjai Provinsi Sulawesi Selatan. Teknik penentuan lokasi desa pada penelitian ini dilakukan secara sengaja (purposive) dengan mempertimbangkan kecamatan yang memiliki hamparan tanaman komoditi unggulan yakni komoditi sayuran dan ternak sapi.

\section{b. Populasi dan Sampel}

Penelitian ini mengkaji faktor-faktor yang mempengaruhi kinerja pelayanan transportasi dalam pengembangan komoditi unggulan di Kecamatan Sinjai Barat. Oleh karenanya yang menjadi populasi dalam penelitian ini adalah petani sebagai pelaku kegiatan komoditi unggulan sayuran dan ternak sapi di Kecamatan Sinjai Barat serta para pakar yang mendalami bidang transportasi dan komoditi unggulan.

Sampel penelitian ditetapkan mengikuti pendapat Roscoe (Sugiono, 2003), yang menyatakan bahwa ukuran sampel untuk penelitian deskriptif yang layak digunakan adalah antara 30 hingga 500 orang. Berdasarkan pendapat tersebut, maka ditetapkan jumlah sampel responden penelitian sebanyak 100 orang, dengan pertimbangan telah melebihi ambang batas kriteria Roscoe, yakni batasan minimal 30 orang. Sampel petani responden diambil sebanyak 10 orang pada setiap desa di Kecamatan Sinjai Barat serta sampel pakar diambil sebanyak 10 orang. Pengambilan sampel responden dilakukan secara purporssive sampling dimana sampel yang terpilih adalah mereka-mereka yang memahami benar tentang persoalan dan permasalahan penelitian ini.

\section{c. Jenis dan Sumber Data}

Data yang dikumpulkan terdiri dari dua jenis, yaitu: 1. Data sekunder, yang diperoleh melalui studi kepustakaan, laporan dan dokumen yang berkaitan dengan masalah penelitian. Data sekunder yang dikumpulkan dalam penelitian ini terdiri dari kondisi transportasi dan komoditi unggulan Kecamatan Sinjai Barat yang ada dilapangan, 2. Data Primer, terdiri dari data penilaian responden tentang faktor yang menjadi penentu kinerja pelayanan transportasi dalam pengembangan komoditi unggulan. Data primer ini diperoleh melalui:

Wawancara yaitu salah satu teknik pengumpulan data yang dilakukan dengan cara mengadakan tanya jawab, baik secara langsung maupun tidak langsung secara tatap muka dengan sumber data.

Observasi merupakan salah satu teknik pengumpulan data dimana peneliti mengadakan pengamatan dan pencatatan secara sistematis terhadap objek yang diteliti dilapangan.

\section{d. Teknik Pengumpulan Data}

Instrumentasi merupakan hal yang sangat penting dalam melaksanakan penelitian, karena dengan instrument yang baik akan diperoleh data atau informasi yang relevan dengan tujuan penelitian. Instrument dalam pengumpulan data yang akan dilakukan dalam penelitian ini adalah kuisioner dimana ada sejumlah pertanyaan tertulis yang digunakan untuk memperoleh informasi yang berhubungan dengan penelitian.

\section{e. Intrumen Penelitian}

Instrument yang baik harus memenuhi 2 (dua) persyaratan penting yaitu valid dan reliable, untuk itu perlu dilakukan uji validitas dan uji reliabilitas.

\section{Uji Validitas}

Menurut Arikunto (1991), Uji kesahihan (Validity test), adalah suatu ukuran yang menunjukkan tingkat keandalan atau kesahihan suatu alat ukur. Alat ukur yang kurang valid berarti memiliki validitas rendah. Untuk menguji validitas alat ukur, terlebih dahulu dicari harga korelasi antara bagian-bagian dari alat ukur secara keseluruhan dengan cara mengkorelasikan setiap butir alat ukur dengan skor total yang merupakan jumlah tiap skor butir, dengan rumus "Pearson Product Moment" : 


$$
\mathrm{r}=\frac{N\left(\sum X Y\right)-\left(\sum X \sum Y\right)}{\left[N \sum X^{2}-\left(\sum X\right)^{2}\right]\left[N \sum Y^{2}-\left(\sum Y\right)^{2}\right]}
$$

Keterangan :

$\mathrm{r}=$ Koefisien validitas

$\mathrm{N}=$ Jumlah responden

$\mathrm{X}=$ Skor item

$\mathrm{Y}=$ Skor total

Koefisien validitas dianggap signifikan jika $\mathrm{r}$ hitung $>\mathrm{r}$ tabel.

\section{Uji Reliability (Reliability test)}

Suatu uji instrument yang dipakai untuk menunjukkan sejauh mana hasil pengukuran dapat konsisten apabila dilakukan pengukuran oleh orang lain (Suryabrata, 2006). Bila suatu alat pengukur dipakai dua kali untuk mengukur gejala yang sama dan hasil pengukuran yang diperoleh relative konsisten, maka alat pengukur tersebut reliabel. Data dari hasil uji coba dihitung dengan menggunakan metode belah dua (Split Half) (Ancok, 1995). Dengan menggunakan rumus "Spearman Brown", yaitu :

Keterangan:

$$
\mathrm{R}=\frac{2 \times r}{1+r}
$$

$\mathrm{R}=$ Angka reliabilitas keseluruhan item

$\mathrm{r}=$ Angka korelasi Product Moment antara belahan.

\section{f. $\quad$ Analisis Data dan Pengujian Hipotesis}

Data yang diperoleh dari lapangan ditabulasi dan dianalisis sesuai dengan tujuan penelitian. Pengujian hipotesis dilakukan untuk melihat pengaruh bebas $\mathrm{x}$ terhadap variabel terikat $\mathrm{y}$.

Untuk menganalisis data digunakan statistik parametrik dengan alat analisis regresi linier berganda, namun karena bentuk data adalah ordinal, sedangkan regresi linier berganda mensyaratkan data berbentuk interval sehingga transformasi pengukuran dengan menggunakan Method succesive interval (MSI) dengan bantuan program Microsoft Exel 2007.

Method of Successive Interval (MSI) merupakan suatu metode yang digunakan untuk menaikkan tingkat pengukuran dari ordinal ke interval. Sarjono dan Winda (2011) mengemukakan langkah-langkah MSI adalah sebagai berikut:

a. Memperhatikan setiap item pertanyaan.

b. Untuk setiap item dihitung frekuensin jawaban (f), beberapa responden yang mendapat skor 1, 2, 3 .

c. Menentukan proporsi (p) dengan cara membagi frekuensi dengan jumlah responden.

d. Menghitung proporsi kumulatif.

e. Menghitung nilai $\mathrm{Z}$ untuk setiap proporsi kumulatif yang diperoleh dengan menggunakan table.

Selain analisis data secara kuantitatif, analisis data kualitatif juga dilakukan untuk melengkapi analisis data keseluruhan. Analisis kualitatif dilakukan secara deskriptif dengan menggunakan hasil-hasil observasi dan catatan selama proses pengumpulan data dilapangan.

\section{Hasil dan Pembahasan}

Penelitian ini menggunakan model penelitian kualitatif. Penelitian kuali tatif bertujuan memperoleh gambaran seutuhnya mengenai suatu hal menurut pandangan manusia yang diteliti. Penelitian kualitatif berhubungan dengan ide, persepsi, pendapat, atau kepercayaan orang yang diteliti; kesemuanya tidak dapat diukur dengan angka (Sulistyo-Basuki, 2006:78).

\section{a. Uji Linearitas}

Uji linearitas merupakan pengujian yang bertujuan untuk mengetahui apakah regresi bersifat linier ataukah tidak.Uji linearitas dalam penelitian ini menggunakan tabel ANOVA variabel $\mathrm{X}$ dan $\mathrm{Y}$ dari nilai signifikan. Apabila nilai signifikan dari tabel ANOVA $<0,05$, maka dapat disimpulkan bahwa hubungan variabel $\mathrm{x}$ dan $\mathrm{y}$ bersifat linier. Uji linieritas dalam penelitian ini menggunakan SPSS v.21.dengan hasil pengujian sebagai berikut.

Tabel 1. Tabel Pengujian Linearitas (hasil olahan SPSS)

\begin{tabular}{lrrrrr}
\multicolumn{6}{c}{ ANOVA $^{\mathrm{a}}$} \\
\hline Model & Sum of Square & \multicolumn{1}{c}{ df } & Mean Square & \multicolumn{1}{c}{ F } & Sig. \\
\hline Regression & 27.146 & 4 & 6.787 & 55.561 & $.000^{\mathrm{b}}$ \\
Residual & 11.604 & 95 & .122 & & \\
Total & 38.750 & 99 & & & \\
\hline
\end{tabular}

a. Dependent Variable: Y

b. Predictors: (Constant), X4, X2, X1, X5

Berdasarkan Tabel 1 tersebut dapat dilihat bahwa nilai signifikan dari tabel ANOVA sebesar 0,000., kurang dari nilai signifikan $0,05(0,000<0,05)$, yang artinya adalah hubungan variabel $\mathrm{Y}$ dan semua variabel $\mathrm{X}$ bersifat linear.

\section{b. Uji Korelasi}

Metode ini dimaksudkan untuk melihat hubungan antara variabel bebas dengan variabel tidak bebas dan antar sesama variabel bebas. Jika antar variabel bebas mempunyai nilai korelasi > 0,6, maka salah satu dari variable bebas tersebut dihapuskan karena sudah saling mewakili satu sama lain. Untuk mengetahui variabel bebas apa yang dihapuskan, maka dilihat hubungan variabel bebas dan variabel tidak bebas yang mempunyai nilai korelasi lebih besar dengan variabel tidak bebas harus dipertahankan

Tabel 2. Interpretasi Nilai $r$

\begin{tabular}{cc}
\hline $\mathrm{r}$ & Interpretasi \\
\hline $0,00-0,19$ & Sangat rendah \\
$0,20-0,39$ & Rendah \\
$0,40-0,59$ & sedang \\
$0,60-0,79$ & Tinggi \\
$0,80-1,00$ & Sangat tinggi \\
\hline
\end{tabular}

Sumber : Prof. Dr. Jogiyanto HM, MBA,Akt. (2011).

Berikut hasil korelasi antar variabel bebas dan variabel tidak bebas terdapat pada Tabel 3 .

Tabel 3. Korelasi antar Variabel Bebas dan Variabel Tidak Bebas

\begin{tabular}{cllllll}
\hline Correlation & Y & X1 & X2 & X3 & X4 & X5 \\
\hline Y & 1 & - & - & - & - & - \\
X1 & 0,444 & 1 & - & - & - & - \\
X2 & 0,742 & 0,444 & 1 & - & - & - \\
X3 & 0,603 & 0,361 & 0,603 & 1 & - & - \\
X4 & 0,562 & 0,515 & 0,412 & 0,335 & 1 & - \\
X5 & 0,605 & 0,545 & 0,363 & 0,393 & 0,562 & 1 \\
\hline
\end{tabular}

Dapat dilihat pada Tabel 3 diatas bahwa variabel bebas X2 dan X3 mempunyai korelasi satu sama lain sangat tinggi. Sehingga perlu diadakan proses eliminasi antar kedua variabel bebas tersebut. Untuk menentukan variabel manakah yang akan digunakan, maka dipilih berdasarkan nilai yang paling tinggi dari 
variabel bebas terhadap variabel terikat. Berdasarkan nilai pada Tabel 3 ditentukan bahwa variabel bebas yang digunakan adalah variabel $\mathrm{X} 2$ karena nilaikorelasi variabel X2 terhadap variabel $\mathrm{Y}$ lebih besar dibandingkan nilai korelasi variabel X3 terhadap variabel Y.

\section{c. Koefisien Determinasi}

Koefisien determinasi pada intinya mengukur seberapa jauh kemampuan model dalam menerangkan variasi variabel.Koefisien determinasi digunakan pada penelitian ini karena dapat menjelaskan kebaikan dari model regresi dalam variabel bebas. Semakin tinggi nilai koefisien determinasi maka akan semakin baik pula kemampuan variabel bebas dalam menjelaskan variabel terikat. Nilai koefisien determinasi adalah antara nol dan satu. Nilai $\mathrm{R}^{2}$ yang kecil berarti kamempuan variabelvariabel bebas dalam menjelaskan variasi variabel terikat amat terbatas. Nilai yang mendekati satu berarti variabelvariabel bebas memberikan hamper semua informasi yang dibutuhkan untuk memprediksi variasi variabel terikat. Dengan menggunakan SPSS v.21.0 diperoleh koefisien determinasi sebagai berikut :

Tabel 4. Koefisien Determinasi (Hasil Olahan SPSS)

\begin{tabular}{lllrrr}
\hline \multicolumn{5}{c}{ Model Summary } \\
\hline Model & $\mathrm{R}$ & R Square & $\begin{array}{c}\text { Adjusted R } \\
\text { Square }\end{array}$ & $\begin{array}{c}\text { Std. Error of the } \\
\text { Estimate }\end{array}$ \\
\hline 1 & $.837^{\mathrm{a}}$ & .701 & .688 & .349 \\
\hline a. Predictors: (Constant), X4, X2, X1, X5
\end{tabular}

Dari hasil output SPSS tersebut, maka dapat dilihat bahwa nilai koefisien determinasi atau $\mathrm{R}$ square sebesar 0,701 atau $70,1 \%$. Hal ini menunjukkan bahwa variabel yang diteliti memberikan pengaruh terhadap loyalitas sebesar 70,1\% sedangkan sisanya dipengaruhi variabel yang tidak diteliti.

\section{d. Pengujian Multikolinieritas}

Pengujian multikolinieritas bertujuan untuk menguji apakah model regresi ditemukan adanya korelasi antar variabel bebas (independen).Model regresi yang baik seharusnya tidak terjadi korelasi diantara variabel bebas (tidak terjadi multikolinearitas). Jika variabel bebas saling berkorelasi, maka variabel-variabel ini tidak orthogonal, yakni variabel bebas yang nilai kolerasi antar sesama variabel bebas sama dengan nol. Dengan nilai toleransi (tolerance, TOL) dan factor inflasi varians (Variance Inflation Factor, VIF). Kriterianya, jika toleransi sama dengan satu atau mendekati satu dan nilai VIF <10 maka tidak ada gejala multikolinearitas.

Sebaliknya apabila nilai toleransi tidak sama dengan satu dan mendekati nol dan nilai VIF >10, Maka Diduga Ada Gejala Multikolinearitas. Penentuan apakah terjadi multikolinearitas tergantung pada nilai tolerance dan VIF (Variance Inflation Factor) yang tetdapat pada program SPSS. Adapun hasil pengujiannya terdapat pada tabel 5 dibawah ini.
Tabel 5. Hasil Pengujian Multikolinearitas (SPSS)

\begin{tabular}{|c|c|c|c|c|c|c|c|c|c|c|c|}
\hline \multicolumn{12}{|c|}{ Coefficients ${ }^{\mathrm{a}}$} \\
\hline \multirow{2}{*}{\multicolumn{2}{|c|}{ Model }} & \multicolumn{2}{|c|}{$\begin{array}{c}\text { Unstandardized } \\
\text { Coefficients }\end{array}$} & \multirow{2}{*}{\begin{tabular}{|c|}
$\begin{array}{c}\text { Standardized } \\
\text { Coefficients }\end{array}$ \\
Beta \\
\end{tabular}} & \multirow[t]{2}{*}{$\mathrm{t}$} & \multirow[t]{2}{*}{ Sig. } & \multicolumn{3}{|c|}{ Correlations } & \multicolumn{2}{|c|}{$\begin{array}{c}\text { Collinearity } \\
\text { Statistics }\end{array}$} \\
\hline & & B & $\begin{array}{l}\text { Std. } \\
\text { Error }\end{array}$ & & & & $\begin{array}{l}\text { Zero- } \\
\text { order }\end{array}$ & Partial & Part & Tolerance & VIF \\
\hline \multirow{5}{*}{1} & (Constant) & .092 & .312 & & .294 & .770 & & & & & \\
\hline & $x 1$ & -.119 & .091 & -.095 & -1.311 & 193 & .444 & -133 & -074 & .597 & 1.674 \\
\hline & $x 2$ & .587 & .065 & .587 & 9.065 & .000 & .742 & .681 & .509 & .753 & 1.328 \\
\hline & $X_{4}$ & .203 & .084 & .175 & 2.405 & .018 & .562 & .240 & .135 & .599 & 1.671 \\
\hline & $\times 5$ & .325 & .069 & .346 & 4.741 & .000 & .605 & .437 & .266 & .591 & 1.691 \\
\hline
\end{tabular}

Berdasarkan hasil pengujian diatas, baik nilai tolerance maupun VIF antar variabel satu sama lain memenuhi nilai persyaratan sehingga dapat disimpulkan bahwa tidak terjadi multikolinearitas.

Setelah dilakukan pengujian regresi linier dengan beberapa tahap baik dari segi uji linearitas, uji korelasi, uji koefisien determinasi dan uji multikolinearitas maka didapatkan persamaan regresi sesuai olahan SPSS, yakni :

$\mathrm{Y}=0,092+(-0,119) \cdot \mathrm{X}_{1}+0,587 \cdot \mathrm{X}_{2}+0,203 \cdot \mathrm{X}_{4}+0,325 \cdot \mathrm{X}_{5}$ $\left(R^{2}=0,701\right)$

\section{Kesimpulan dan Saran}

Hasil pembahasan dapat disimpulkan bahwa faktorfaktor yang mempengaruhi terjadinya pengembangan wilayah mencakup variable sarana dan prasarana, variable sistem transportasi, variable Kebijakan Pemerintah, variable Sumber Daya Manusia dan variable Perilaku Pengguna Jasa serta variable Kinerja PelayananTransportasi Berdasarkan persamaan model pada pengembangan wilayah masyarakat memberikan respon: Untuk sarana dan prasasarana transportasi (X1) sebesar, 75 dari 100 atau $75 \%$ responden menyatakan penting. Sistem operasi transportasi (X2) sebesar 55 dari 100 atau 55\% responden menyatakan penting. Kebijakan pemerintah daerah (X3) sebesar 55 dari 100 respondenatau $55 \%$ responden menyatakan penting. Sumber daya manusia (X4) sebesar 65 dari 100 responden atau 65\% responden menyatakan penting. Perilaku Pengguna Jasa (X5) sebesar 55 dari 100 responden atau $55 \%$ responden menyatakan penting.

\section{Daftar Pustaka}

Ancok, J.1995. Metode Penelitian Survey Validitas. Penerbit Andi, Jogyakara

Bintarto, R. 1982. Interaksi Desa-Kota dan Permasalahannya. Ghalia Indonesia, Jakarta.

BPS Kabupten Sinjai, 2012. Kabupaten Sinjai Dalam Angka. Kantor Statistik Kabupaten Sinjai, Sinjai.

Daljoeni, N., 2003. Geografi Desa dan Kota. Alumni, Bandung.

Dinas Pertanian Kabupaten Sinjai, 2011. Kontribusi Sektor Pertanian Terhadap PDRB Kabupaten Sinjai. Dinas Pertanian, Sinjai.

Haryadi Sarjono, Winda Julianita. 2011. SPSS vs LISREL sebuah pengantar Aplikasi untuk Riset. Penerbit Salemba Empat. Jakarta

Hurst, E., 1974. Transportation Geography: Comments and Readings. New York United States. 
Margareta, H., 2000. Perbaikan Sistem Transportasi di Perdesaan di Era Otonomi Daerah. Makalah Geografi Transportasi Fakultas Geografi UGM, Yogyakarta.

Nasution, A., 1996. Menajemen Transportasi. Ghalia Indonesia, Jakarta .

Pahlevi, K.R., 2006. Studi Evaluasi Kinerja Bus Ekonomi Rute Malang-Surabaya. Universitas Muhammadiyah Malang, Malang.

Salim, H.A., 2000. Manajemen Transportasi. Raja Grafindo Persada, Jakarta.

, 2012. Manajemen Transportasi. Jakarta: Rajawali Press.

Schumer, 1974. Planning for Public Transport. Hutchinson, London.

Soesilo, Budi Hartanto (1998), Sistem dan Rekayasa Transportasi, Jurusan Teknik Sipil Universitas Kristen Maranatha, Bandung.

Soesilo, N.I., 1999. Ekonomi Perencanaan dan Manajemen Kota. Universitas Indonesia, Jakarta.

Sugiyono, 2003. Metode Penelitian Administrasi. Alfabeta, Bandung.

Sumadi Suryabrata. (2006). Psikologi Pendidikan. Jakarta: PT Raja Grafindo Persada.

Tamin, O.Z., 1997. Perencanaan dan Pemodelan Transportasi. ITB Press, Bandung.

Warpani, Suwardjoko. 1990. Merencanakan Sistem Perangkutan. Bandung: Penerbit ITB. 